\title{
A scientific attempt to Identify and prioritize the elements effective on the development of strategic thinking in the MAPNA Group Corporation
}

\author{
Abbas Monavarian ${ }^{1}$ and Mitra Hashemi ${ }^{2}$
}

\begin{abstract}
1 Professor and Faculty Member, Faculty of Management, Tehran University, Tehran, Iran.
2 Master's Degree in Management of MBA Strategic Orientation, Mehr Alborz Institute of Higher Education, Iran. E-mail: hmitra50@gmail.com
\end{abstract}

\begin{abstract}
The purpose of the present study was to identify the effective elements on strategic thinking in the MAPNA Group Corporation whilst its' method of conduction is a mixed one. Once interviews were completed, 44 raw datasets were identified which were transformed into 28 mutual codes that were further categorized in 6 concepts that felt under two categories; ultimately a theory was made. Among the several elements that have been found effective on strategic thinking it can be referred to organizational structure, reward system, organizational culture, organizational agility, organizational outlook, organizational creativity and innovation. In the qualitative part, the population of the present study includes the entire experts and elites of the MAPNA Group Corporation and the identified elements have been subjected to numerical analyses in form of hypotheses. In addition in the quantitative part, the population of the study includes the entire employees of the MAPNA Group Corporation among whom 154 individuals have been selected as the samples of the study. results of the study have shown that the identified elements are not of equal importance and in terms of priority these elements respectively include organizational structure, organizational agility, organizational outlook, organizational creativity and innovation g reward system, organizational culture.

Keywords: strategic thinking, employees, MAPNA Group Corporation.
\end{abstract}

\section{INTRODUCTION}

In spite of the introduction of the phrase of "strategic thinking" in the past few years, still only a few scientific studies have been conducted regarding it and hence, there is a need for conduction of more studies in this regard so that the former concept is understood better. Such an understanding works like a lost loop in the chain of strategic management studies and helps us with creating a more concrete image of strategic decision making. In addition it may help executive managers with development of certain strategies aimed at the promotion of organizational strategic thinking. Since without the understanding of the concept of strategic thinking, unlike the concept of strategic planning, we are accepting the risk of adding a new word to the dictionary of strategic management that is not related to executive managers, therefore it seems necessary for the researchers of this field to make an effort towards explaining and or describing the concept of strategic thinking (LIDETKA, 1988: 120).

As the competitions between the current industries intensify, the importance of undertaking studies related to development, codification and, execution of different strategies becomes bolder. Increased changes in both the internal and external environments of organizations have created more focus on strategy codification and strategic 
management in such organizations. Since manufacturing organizations are need of effective local, regional and global competition in, therefore they are ought to determine their strategic priorities and also codify certain strategies based on the former priorities (KATE, 2004: 904). The basis of every strategic program is the analysis of data and this type of thinking (convergent thinking) lacks the required strength for creativity as the main essence of evolutionary strategies. Mintzberg has pointed out in one of his studies that due to its analytic nature, strategic planning leads to an executive planning; and what gives effectiveness to strategies is creative synthesis (MINTZBERG, 1994: 112). In addition Turner has also stated that we have a limited capacity in predicting the future; in fact when the world is rapidly and unpredictably changing and while there is no control on essential sources, organizations cannot formulate and effectuate strategies (TURNER, 1998: 102). Hence in the current evolving and unpredictable environment, strategic thinking is considered as a suitable strategic approach for organizations (GHAFARIAN, 2003: 34).

Mintzberg believed that the concept of strategic planning is an ambiguous concept and therefore it needed a clear definition. Nowadays, not only the concept of strategic planning is not clear, but also with the introduction of the term of Strategic Thinking, the situation has become even more complicated (HERCULES, 1998: 483). Strategic thinking is associated with the clarification of the accepted approach in terms of traditional strategic planning and the flattening of the objections regarding it. However, only a few studies have been conducted regarding its process and elements and its manner of involvement in the process of planning (LIDETKA, 1988: 120). For example, Stobart has pointed to the crucial importance of managerial thinking but he has missed the elements related to strategic decision making. He has stated that since strategic management elaborates on the activities of managers and since managers themselves must think about different strategies, there is a question why researchers are not conducting more studies regarding the managers' manners of thinking. On the other hand, Garret has also pointed to the importance of conduction of more studies while stating that strategic thinking studies have been underscored. A group of experts in the United States of America have introduced strategic thinking as one of the ten most important and crucial future research subjects. In this regard experimental studies too have shown a need for more studies in the field of strategic thinking. For example Garret has pointed out that most managers deputies in the society of London's managers have not been subjected to any training aimed at making them competent for guidance of their businesses. In addition Bone showed that the majority of senior managers of 35 of the Australia's 100 largest corporations believe that the main problem their organization is faced with is the lack of strategic thinking (BONE, 2001: 63).

The importance of the present study lies in the fact that most previously conducted studies in this context have made use of qualitative methods for the identification of elements of strategic thinking. In fact the present study combines these elements and proposes a comprehensive model. In addition by the prioritization of the elements effective on the development of strategic 
thinking in the MAPNA Group Corporation, one can achieve successes in the realization of the development of strategic thinking and improvement of his/her corporate efficiency through focusing on important and high-priority elements.

Considering the above mentioned content, the present study tries to identify the elements effective on the development of strategic thinking in the MAPNA Group Corporation and hence, the research questions are as follows:

1- What elements are effective on the development of strategic thinking in the MAPNA Group Co.?

2- What are the priorities of these elements?

\section{THEORETICAL REVIEW OF LITERATURE}

\section{Strategic Thinking}

Strategic thinking is a method for understanding of the main orientations and incentives effective on the organization, while creative thinking is associated with an organization's challenges through constructive and positive negotiations. In other words, the focus is on the identification and development of opportunities with the aim of value creation through the provision of a creative conversing environment for those who can be effective in the organization's main orientations (AMIRAN, 2011: 33).

Mintzberg (1998) claims that strategic planning is a process that can be realized only if strategic thinking is already realized; not unlike him, Grate (1995) hold a similar view and believes that strategic thinking is a process through which the senior managers of organizations can isolate themselves from routine managerial processes and crises so that they can adopt a different view of their organizations and their variable environments (FARHANGI \& NIRI, 2010).

In his famous book titled as "The Thinking of an Strategist", Kenny I chi Umi (1999) states: if you fail to identify the main issues, no matter how hard you both physically and mentally push yourself and your employees, the only results you will get would be confusion and failure. Henry Mintzberg believes that strategic thinking is an integrated scheme of the business in one's mind. On the other hand, Garry Hamel considers it as an artistic architecture of strategy based on the business' creativity and comprehension. Ralf $\mathrm{S}$. identifies it as planning based on learning (MOSHABAKI, 2008).

\section{Proposed Models in Strategic Thinking}

Strategic thinking is a descriptive school in strategy and hence, instead of prescribed procedures and methodologies, it is the describing models that provide the manner of the approach. Sevteral models have been proposed for strategic thinking, each of which elaborates on certain aspects of the concepts and the process of formation of strategic thinking. in the present study, four credible models of strategic thinking would be introduced (ZAREI, GHOLI HA, 2010).

\section{a. Gin Lidice's model of elements of strategic thinking}

A scheme of the system, focus on goals, smart opportunism, in time thinking, proceeding with hypotheses 
Diagram 2, Gin Lidice's model of strategic thinking

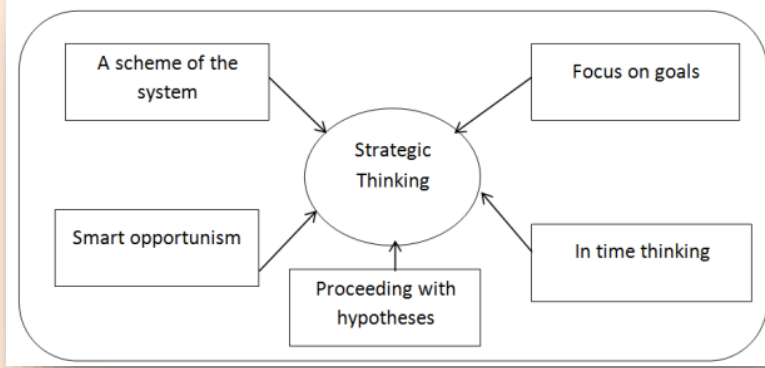

\section{b. Gary Hamel's Model of Strategic}

\section{Thinking}

Gary Hamel has proposed a model for strategic thinking whose main essence is innovation. Hamel defines strategic innovation for stakeholders with the two characteristics of creation of new values and creation of new wealth; while considering it as the necessary condition for survival and growth of firms in today's disintegrated fullof-evolution environment. Ultimately he proposes a model including five recommendations: listen to the new voices, establish new communications, provide new enthusiasm in your organizations, welcome new experiences and, illustrate a new intellectual framework for your organizations (MIR AFTAB ZADEH ET AL., 2013).

\section{Peter Williamson's Model of Strate-} gic Thinking

For the subject of strategic thinking, Peter Williamson has proposed the model of future options. He believes that the main reason for failure of organizations is the loss of maneuverability and hence, he proposes creating options for future as an effective solution. Reveal the hidden limitations, establish the necessary processes, optimize your options and, integrate planning and opportunism.

Despite of the different perspectives the former models adopt towards the issue of strategy and strategic thinking, all of them emphasize on learning as an effective method for development and understanding regarding customers and markets (AHMADI, 2012).

d. Kiani and Ghafarian's Model of Elements of Strategic Thinking

$1^{\text {st }}$ Command: before seeking information, seek learning from the environment of the business: many of the aspects of businesses are only understood through real experience in the market.

$2^{\text {nd }}$ Command: prior to responding to the discovered needs, seek the unsatisfied needs of the market: creating value for customers is only feasible through responding to both the hidden and evident needs of them.

$3^{\text {rd }}$ Command: in order to reach your goals, think more about shortcuts than speed: as there are many ways to reach a destination, there are also many ways to respond to customers' needs.

$4^{\text {th }}$ Command: creation of innovative solutions requires a divergent style of thinking. Different solutions must be sought for a single problem; solutions that turn the impossible in the conventional intellectual system into possible in the new intellectual system.

$5^{\text {th }}$ Command: shortcuts towards market needs are golden keys to interests embedded in opportunities (KHORSANDI NOWSHAHRI, 2012: 45-46).

\section{e. Goldman's Model of Strategic Thin- king}

Figure 1, Goldman's model of strategic thinking

Systematic thinking Smart opportunism Providence Conceptual thinking 


\section{EXPERIENTIAL REVIEW OF LITERATURE}

\begin{tabular}{|c|c|c|}
\hline Title & Author & Findings \\
\hline $\begin{array}{l}\text { Investigation } \\
\text { of strategic } \\
\text { thinking } \\
\text { among the } \\
\text { strategist } \\
\text { managers of } \\
\text { Holdings in } \\
\text { Iran }\end{array}$ & $\begin{array}{l}\text { Seyed Kalali, } \\
\text { Nader (2015) }\end{array}$ & 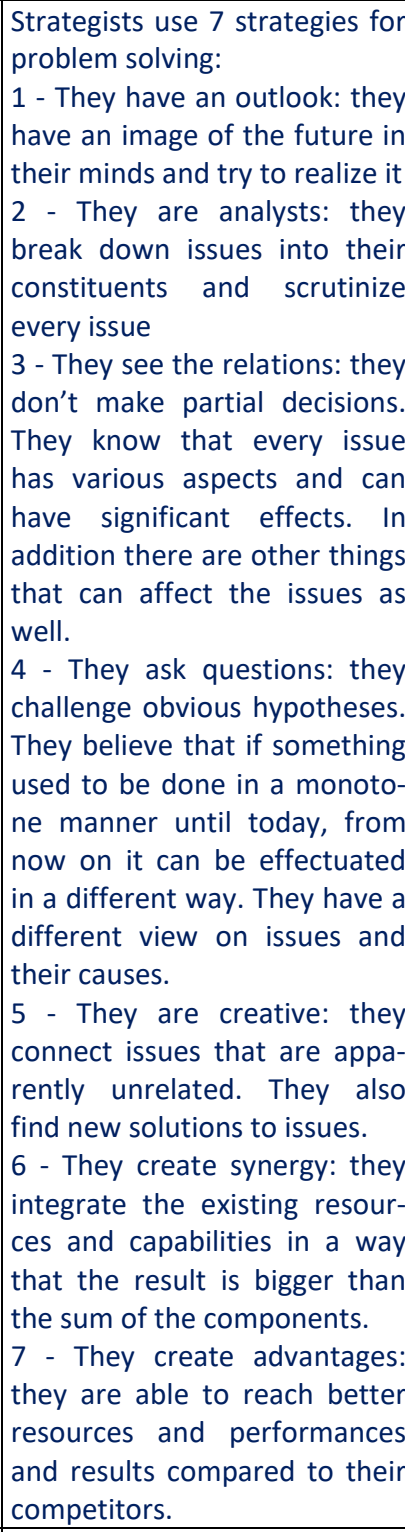 \\
\hline $\begin{array}{l}\text { Investigation } \\
\text { of coopera- } \\
\text { tion in crea- } \\
\text { tion of strate- } \\
\text { gic thinking } \\
\text { among the } \\
\text { managers and } \\
\text { beneficiaries } \\
\text { of pioneering } \\
\text { companies }\end{array}$ & $\begin{array}{l}\text { Kariman } \\
\text { Ozkan \& } \\
\text { Nokat Roma- } \\
\text { somi (2016) }\end{array}$ & $\begin{array}{l}\text { This article states that in } \\
\text { pioneering companies, there } \\
\text { should exist a common inte- } \\
\text { raction system between the } \\
\text { beneficiaries and the organiza- } \\
\text { tion with its basis being the } \\
\text { creation of value chain. The } \\
\text { findings of this study have } \\
\text { shown that these corporations } \\
\text { can create suitable strategies } \\
\text { and initiate the common } \\
\text { process of cooperation and } \\
\text { create new opportunities } \\
\text { along with the customers, } \\
\text { associates and other beneficia- } \\
\text { ries. In addition through the }\end{array}$ \\
\hline
\end{tabular}

\begin{tabular}{|c|c|c|}
\hline & & $\begin{array}{l}\text { usage of this system, corpora- } \\
\text { tions can activate the compe- } \\
\text { tencies of the managers } \\
\text { outside the organizations }\end{array}$ \\
\hline $\begin{array}{l}\text { Learning } \\
\text { strategic } \\
\text { thinking } \\
\text { through } \\
\text { empirical } \\
\text { evidence }\end{array}$ & $\begin{array}{l}\text { John Benton, } \\
\text { John Stoles, } \\
\text { Sanchez } \\
\text { Louie (2016) }\end{array}$ & $\begin{array}{l}\text { Strategic behavior is crucially } \\
\text { important for corporate per- } \\
\text { formance, especially in compe- } \\
\text { titive environments. On this } \\
\text { basis designing a suitable } \\
\text { strategy is a key issue for } \\
\text { corporations. Designing a } \\
\text { strategy requires a combina- } \\
\text { tion of strategic thinking } \\
\text { including the analysis of the } \\
\text { strategic environment of } \\
\text { corporation, defining future } \\
\text { outlooks, innovation in crea- } \\
\text { tion of new ideas and ultima- } \\
\text { tely, the strategic planning for } \\
\text { these thoughts. In order to } \\
\text { prepare a strategic environ- } \\
\text { ment in a corporation, the } \\
\text { managers and the employees } \\
\text { must have a tendency for } \\
\text { active participation in strategic } \\
\text { decision makings. In this } \\
\text { research, firstly two groups of } \\
\text { people with almost similar } \\
\text { skills and competencies have } \\
\text { been selected. The first group } \\
\text { was empirically trained with } \\
\text { instructions regarding the } \\
\text { processes of strategic thinking } \\
\text { and behavior while the second } \\
\text { group only watched the trai- } \\
\text { ning of the first group. Results } \\
\text { showed that in terms of num- } \\
\text { ber of adopted strategic } \\
\text { decisions, the first group was } \\
\text { more successful than the } \\
\text { second group. }\end{array}$ \\
\hline $\begin{array}{lr}\text { The effect } & \text { of } \\
\text { design } & \text { of } \\
\text { products } & \text { and } \\
\text { services } & \text { of } \\
\text { systems in the } \\
\text { domain } \\
\text { strategic } \\
\text { thinking } \\
\text { Japan }\end{array}$ & \begin{tabular}{|lr} 
Yutaro & Ne- \\
matode, & \\
Takashi & Fuji \\
Varo, & Satoshi \\
Miso roji \\
and, & Yushiki \\
Shimomoro
\end{tabular} & $\begin{array}{l}\text { The authors of this study have } \\
\text { elaborated on the deve- } \\
\text { lopment of strategic thinking } \\
\text { and effects of educational } \\
\text { business game on the users. } \\
\text { By entering these simulated } \\
\text { workshops, the users face } \\
\text { several organizational challen- } \\
\text { ges and problems for which } \\
\text { they must make strategic } \\
\text { decisions. Studies have shown } \\
\text { that these workshops can } \\
\text { teach the users how to change } \\
\text { their ways of thinking and how } \\
\text { to make use of effective } \\
\text { learning through strategic } \\
\text { thinking in a simulated busi- } \\
\text { ness environment. Hence the } \\
\text { users can be more strategic in }\end{array}$ \\
\hline
\end{tabular}




\begin{tabular}{|c|c|c|}
\hline & & $\begin{array}{l}\text { their organizational decision } \\
\text { makings. }\end{array}$ \\
\hline $\begin{array}{l}\text { Provision of a } \\
\text { new model of } \\
\text { strategic } \\
\text { thinking } \\
\text { competence } \\
\text { among the } \\
\text { leaders of } \\
\text { businesses of } \\
\text { Thailand }\end{array}$ & \begin{tabular}{|lr} 
Pelion & Nan- \\
tamnap, & Lega \\
Korana & $\&$ \\
Briar & Algal \\
$(2015)$ &
\end{tabular} & $\begin{array}{l}\text { This research is based on } \\
\text { qualitative methods and } \\
\text { includes interviews with } \\
\text { leaders of industries. In addi- } \\
\text { tion, after the interpretation } \\
\text { of data, this study showed that } \\
\text { leaders who have strategic } \\
\text { thinking should possess the } \\
\text { following seven characteris- } \\
\text { tics: being capable of concep- } \\
\text { tual thinking, imaginary thin- } \\
\text { king, being capable of analytic } \\
\text { thinking, objectivity, creativity } \\
\text { in combining and having the } \\
\text { ability to learn. These are the } \\
\text { skills and capabilities that are } \\
\text { known as the competencies } \\
\text { for strategic thinking. Results } \\
\text { of the study have also shown } \\
\text { that strategic thinking leads to } \\
\text { organizational efficiency and } \\
\text { effectiveness }\end{array}$ \\
\hline
\end{tabular}

\section{METHODS}

In terms of purpose and manner of data collection, the present article is respectively considered as an applied and descriptivesurvey study. in order to carry out the study, firstly 44 raw datasets have been identified through holding interviews with experts. After necessary eliminations, a final number of 28 codes in the form of 6 elements were identified as the main elements related to the subject of the study at hand. Nonetheless, for the purpose of collection of the required research data the researcher has developed and designed a questionnaire considering the identified elements.

The present study's questionnaire was consisted of two main sections:

a) General questions: in this section efforts have been made to collect respondents' basic and demographic information through posing 4 questions.

b) Expert questions: the questionnaire of effective elements on strategic thinking: this part included 28 questions. While designing this part, maximum efforts have been made to keep the questions understandable. Nonetheless, the questions in this section were based on a 5 point Likert Scale. The validity of the questionnaire was approved by experts and professors while the factor analysis method has been used for the determination of construct validity. Nonetheless, the Cronbach's alpha coefficient method has been used for the calculation of the reliability of the questionnaire. To this end, 20 questionnaires were primarily distributed among the samples. The yielded Cronbach's alpha value was 0.805; showing that the questionnaire was of a suitable reliability.

The population of the study includes the entire 250 experts and managers of the MAPNA group Co. during the 2017. Based on the population size and through the application of the Cochran's formula, the size of sample of study was determined as 154 individuals. These samples have been selected through a simple random sampling method. Nonetheless, for the purpose of analysis of the collected data, both descriptive and inferential statistics have been used. In this regard, research variables have firstly been tested using descriptive statistics methods.

In this study, the exploratory and confirmatory factor analysis models are in fact two different approaches towards creation of measurement models. While the loading of an independent variable on a dependent variable in confirmatory models is theoretically and experimentally well-backed-up and that the collected data only specicy the weights of such relationships; in exploratory models there is no primary idea regarding 
connecting which independent variable to which dependent variable and therefore such dependent variables are expected to be identified after the quantitative analysis of the data. Although one can develop both of the exploratory and confirmatory modeling using modeling Software, but the main basis in modeling is confirmatory factor models. In fact the model used in the present study is a confirmatory factor model.

In the present study, the tests of Cronbach's alpha, Kolmogorov-Smirnoff, Binomial test and the Freedman test have been made use of through the SPSS V.23.0 software.

\section{RESULTS}

\section{Analysis of descriptive statistics}

The results regarding the descriptive statistics are shown in the following table.

\begin{tabular}{|c|c|c|c|c|c|c|c|c|c|c|c|c|c|c|c|c|}
\hline Fir & \multicolumn{2}{|c|}{ Gender } & \multicolumn{5}{|c|}{ Age } & \multicolumn{4}{|c|}{ Education } & \multicolumn{5}{|c|}{ Experience } \\
\hline \multirow{2}{*}{ 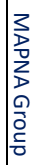 } & $\begin{array}{l}3 \\
\frac{3}{1} \\
\frac{2}{10}\end{array}$ & $\begin{array}{l}\vec{D} \\
\frac{\vec{D}}{3} \\
\frac{0}{\mathbb{D}}\end{array}$ & 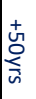 & 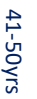 & 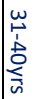 & 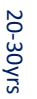 & 告. & 뭄 & $\underset{b}{3}$ & $\underset{\dot{D}}{\infty}$ & ס & 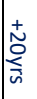 & 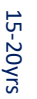 & 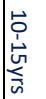 & 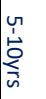 & $\varliminf_{\text {in }}^{\text {in }}$ \\
\hline & 154 & 0 & 7 & 27 & 87 & 33 & & 7 & 41 & 64 & 13 & 6 & 4 & 93 & 36 & 15 \\
\hline
\end{tabular}

*research findings

This section includes the results of confirmatory factor analysis for each and every research variable separately. It is worthy of mentioning that in order to reduce the variables and in order to be able to consider them as latent variables, the obtained factor load should be higher than 0.3. We have considered the matrix of the components and the rotary matrix of the components of the factor loads with values larger than 0.5 as the main factor loads whilst the weaker factor loads have been eliminated. In order to certify the results, the confirmatory factor analysis test has been repeated. The results are shown in the following table:

Table 2: Confirmed factor loads for each organizational element

\begin{tabular}{|c|c|c|c|c|c|}
\hline \multirow[t]{2}{*}{ Factors } & \multirow[t]{2}{*}{$\begin{array}{l}\text { Ques- } \\
\text { tions }\end{array}$} & \multicolumn{2}{|c|}{$\begin{array}{c}\text { Rotational/ } \\
\text { non-rotational }\end{array}$} & \multirow[t]{2}{*}{$\begin{array}{c}\text { Bartlett } \\
\text { significance }\end{array}$} & \multirow[t]{2}{*}{$\begin{array}{c}\text { Factor } \\
\text { load }\end{array}$} \\
\hline & & $\begin{array}{c}\text { Element } \\
1\end{array}$ & $\begin{array}{c}\text { Element } \\
2\end{array}$ & & \\
\hline \multirow{4}{*}{$\begin{array}{l}\text { Organizatio- } \\
\text { nal structure }\end{array}$} & 4 & 0.775 & & 0.000 & 0.775 \\
\hline & & 0.763 & & & 0.763 \\
\hline & & 0.642 & & & 0.642 \\
\hline & & 0.688 & & & 0.688 \\
\hline \multirow{4}{*}{$\begin{array}{c}\text { Organizatio- } \\
\text { nal agility }\end{array}$} & 4 & 0.673 & & 0.000 & 0.673 \\
\hline & & 0.855 & & & 0.855 \\
\hline & & 0.835 & & & 0.835 \\
\hline & & 0.788 & & & 0.788 \\
\hline \multirow{2}{*}{$\begin{array}{l}\text { Reward } \\
\text { System }\end{array}$} & 2 & 0.807 & & 0.000 & 0.807 \\
\hline & & 0.807 & & & 0.807 \\
\hline \multirow{3}{*}{$\begin{array}{l}\text { Organizatio- } \\
\text { nal culture }\end{array}$} & 3 & 0.797 & & 0.000 & 0.797 \\
\hline & & 0.748 & & & 0.748 \\
\hline & & 0.755 & & & 0.755 \\
\hline \multirow{4}{*}{$\begin{array}{l}\text { Organizatio- } \\
\text { nal outlook }\end{array}$} & 4 & 0.750 & & 0.000 & 0.750 \\
\hline & & 0.770 & & & 0.770 \\
\hline & & 0.512 & & & 0.512 \\
\hline & & 0.659 & & & 0.659 \\
\hline \multirow{4}{*}{$\begin{array}{l}\text { Creativity } \\
\text { and innova- } \\
\text { tion }\end{array}$} & 4 & 0.153 & & 0.000 & 0.153 \\
\hline & & 0.013 & & & 0.013 \\
\hline & & 0.853 & & & 0.853 \\
\hline & & 0.842 & & & 0.842 \\
\hline
\end{tabular}

With regard to the results of the factor analysis, since the significance values of the Bartlett test for all elements are smaller than $5 \%$, none of the elements would be eliminated.

Testing the normality of distribution of elements

In order to test the normality of the skewedness and kurtosis of the data distributions, the Shapiro-Wilk and or the Kolmogorov-Smirnoff tests would be used. While testing so, we will test the assumption of the normality of data at the error level of $5 \%$. In this regard if the result of the test 
was a value equal to or larger than 0.05 , it would be concluded that that the data distributions are normal and vice versa. The following is the form of statistical hypotheses considered while testing the normality of data distributions:

$\mathrm{HO}$ : the data distributions related to the variables are normal

$\mathrm{H} 1$ : the data distributions related to the variables are not normal

The one sample test of K-S tends to compare the observed cumulative function with the theoretical cumulative function in a variable. In other words, this test compares the distribution of a trait in a sample with the distribution that is hypothesized for that population.

Table 3: Testing the normality of data

\begin{tabular}{|l|c|c|c|c|c|c|}
\hline & \multicolumn{3}{|c|}{ K-S } & \multicolumn{3}{c|}{ S-W } \\
\cline { 2 - 7 } & Statistic & DF & Sig. & Statistic & DF & Sig. \\
\hline $\begin{array}{l}\text { Organizational } \\
\text { structure }\end{array}$ & 0.115 & 153 & 0.000 & 0.957 & 153 & 0.000 \\
\hline $\begin{array}{l}\text { Organizational } \\
\text { agility }\end{array}$ & 0.141 & 153 & 0.000 & 0.937 & 153 & 0.000 \\
\hline $\begin{array}{l}\text { Reward } \\
\text { system }\end{array}$ & 0.146 & 153 & 0.000 & 0.932 & 153 & 0.000 \\
\hline $\begin{array}{l}\text { Organizational } \\
\text { culture }\end{array}$ & 0.118 & 153 & 0.000 & 0.954 & 153 & 0.000 \\
\hline $\begin{array}{l}\text { Organizational } \\
\text { outlook }\end{array}$ & 0.113 & 153 & 0.000 & 0.967 & 153 & 0.000 \\
\hline $\begin{array}{l}\text { Organizational } \\
\text { creativity }\end{array}$ & 0.205 & 153 & 0.000 & 0.912 & 153 & 0.000 \\
\hline
\end{tabular}

Results of the K-S test prescribed for the research variables show that data none of the distributions related to research elements are normal. Considering the abnormality of the distributions, in order to investigate the effective elements on strategic thinking the ratio test has been used.
Table 4: Results of the Ratio test

\begin{tabular}{|l|c|c|c|c|c|}
\hline \multicolumn{1}{|c|}{ Factor } & Class & Number & $\begin{array}{c}\text { Observed } \\
\text { percentage }\end{array}$ & $\begin{array}{c}\text { Tested } \\
\text { percentage }\end{array}$ & Sig. \\
\hline \multirow{2}{*}{$\begin{array}{l}\text { Organizational } \\
\text { structure }\end{array}$} & $\leq 3$ & 33 & 0.2 & 0.6 & 0.000 \\
\cline { 2 - 5 } & $>3$ & 121 & 0.8 & & \\
\hline \multirow{2}{*}{$\begin{array}{l}\text { Organizational } \\
\text { agility }\end{array}$} & $\leq 3$ & 55 & 0.4 & 0.6 & 0.000 \\
\cline { 2 - 4 } Reward system & $>3$ & 99 & 0.6 & & \\
\cline { 2 - 5 } & $>3$ & 35 & 0.2 & 0.6 & 0.000 \\
\cline { 2 - 5 } $\begin{array}{l}\text { Organizational } \\
\text { culture }\end{array}$ & $\leq 3$ & 27 & 0.2 & 0.6 & 0.000 \\
\cline { 2 - 4 } $\begin{array}{l}\text { Organizational } \\
\text { outlook }\end{array}$ & $>3$ & 127 & 0.8 & 0.6 & 0.000 \\
\cline { 2 - 4 } $\begin{array}{l}\text { Organizational } \\
\text { creativity }\end{array}$ & $>3$ & 126 & 0.8 & 0.6 & 0.000 \\
\cline { 2 - 5 } & $>3$ & 107 & 0.7 & 0.6 & \\
\hline
\end{tabular}

Considering the above table, it is seen that all of the elements have a statistically significant difference from the value of 0.6 and therefore, it is concluded that the elements are effective on the development of strategic thinking.

Freedman test for the prioritization of organizational elements

$\mathrm{HO}$ : there is no statistically significant difference between the organizational elements effective on strategic thinking.

$\mathrm{H} 1$ : there is a statistically significant difference between the organizational elements effective on strategic thinking.

Table 5: Freedman test's statistics

\begin{tabular}{|l|l|}
\hline Statistic & Statistic value \\
\hline Number & 154 \\
\hline Chi-Score & 44.294 \\
\hline F.D & 7 \\
\hline Sig. & 0.000 \\
\hline
\end{tabular}

Considering the Chi-square value of 44.294 and the significance value of 0.000 it is concluded there exist statistically significant differences between the organizational elements effective on the development of strategic thinking. Therefore the $\mathrm{H} 1$ hypothesis is accepted. 
Paired comparison test in case of prioritization of factors:

In order to rank the factors effective on the development of strategic thinking, we have used the paired comparison test in addition to the AHP method. In order to obtain the compatibility rate of the matrixes of the AHP, the following relations have been used:

Calculation of compatibility vector (CV): divide the elements of the vector of weight sum by the vector of proportional weights. The yielding vector is referred to as the compatibility vector.

Calculation of the largest special value of the paired comparisons matrix: in order to do so, the means of the factors of the compatibility vector should be calculated.

Calculation of the index of incompatibility (II): this index is calculated in the following way:

$$
\|=\frac{\lambda_{\max }-n}{n-1}
$$

Calculation of Incompatibility Rate (IR): this rate is calculated as follows:

$$
\mathrm{IR}=\frac{I I}{I R I}
$$

If the incompatibility rate was smaller than or equal to 0.1 , it is concluded that there exists compatibility in paired comparisons. Hence we can continue with our work. But if not so, revisions should be made regarding the paired comparisons.
Table 6: Matrix of paired comparisons of factors effective on the development of strategic thinking

\begin{tabular}{|l|l|l|l|l|l|l|}
\hline & $\begin{array}{l}\text { Organi- } \\
\text { zational } \\
\text { structure }\end{array}$ & $\begin{array}{l}\text { Organi- } \\
\text { zational } \\
\text { agility }\end{array}$ & $\begin{array}{l}\text { Re- } \\
\text { ward } \\
\text { sys- } \\
\text { tem }\end{array}$ & $\begin{array}{l}\text { Organi- } \\
\text { zational } \\
\text { culture }\end{array}$ & $\begin{array}{l}\text { Organi- } \\
\text { zational } \\
\text { creativity } \\
\text { and } \\
\text { innova- } \\
\text { tion }\end{array}$ & $\begin{array}{l}\text { Organi- } \\
\text { zational } \\
\text { outlook }\end{array}$ \\
\hline $\begin{array}{l}\text { Organi- } \\
\text { zational } \\
\text { structure }\end{array}$ & 1 & 0.237 & 0.667 & 0.52 & 0.563 & 0.543 \\
\hline $\begin{array}{l}\text { Organi- } \\
\text { zational } \\
\text { agility }\end{array}$ & 4.21941 & 1 & 1.858 & 1.857 & 2.66 & 3.05 \\
\hline $\begin{array}{l}\text { Reward } \\
\text { system }\end{array}$ & 1.49925 & 0.538213 & 1 & 0.552 & 1.164 & 1.163 \\
\hline $\begin{array}{l}\text { Organi- } \\
\text { zational } \\
\text { culture }\end{array}$ & 1.923 .8 & 0.538503 & 1.811 & 1 & 0.344 & 0.75 \\
\hline $\begin{array}{l}\text { Organi- } \\
\text { zational } \\
\text { creativity } \\
\text { and } \\
\text { innova- } \\
\text { tion }\end{array}$ & 1.7762 & 0.37594 & $\begin{array}{l}0.859 \\
159\end{array}$ & 2.90698 & 1 & 1.309 \\
\hline $\begin{array}{l}\text { Organi- } \\
\text { zational } \\
\text { outlook }\end{array}$ & 1.84162 & 0.327869 & 0.859 & 1.33333 & 0.763942 & 1 \\
\hline
\end{tabular}

Table 7: The output of the matrix of paired comparison of factors effective on the development of strategic thinking

\begin{tabular}{|c|c|c|c|c|}
\hline Main factors & Sub-factors & weights & Ranks & incompatibility \\
\hline $\begin{array}{c}\text { Development } \\
\text { of strategic } \\
\text { thinking }\end{array}$ & $\begin{array}{c}\text { Organizational } \\
\text { culture }\end{array}$ & 0.078839 & 6 & Maximum Eigen \\
\cline { 2 - 4 } & $\begin{array}{c}\text { Organizational } \\
\text { structure }\end{array}$ & 0.328115 & 1 & Value $=6.29515$ \\
\cline { 2 - 4 } & Reward system & 0.139216 & 4 & \multirow{1}{*}{ C.I. $=0.0590299$} \\
\cline { 2 - 4 } & $\begin{array}{c}\text { Organizational } \\
\text { outlook }\end{array}$ & 0.14012 & 3 & \\
\cline { 2 - 4 } & $\begin{array}{c}\text { Organizational } \\
\text { creativity and } \\
\text { innovation }\end{array}$ & 0.181849 & 2 & \\
\cline { 2 - 4 } & $\begin{array}{c}\text { Organizational } \\
\text { agility }\end{array}$ & 0.131861 & 5 & \\
\hline
\end{tabular}

Considering the table 8 , results of analysis of the data collected through the questionnaires using the AHP technic show that the prioritization of factors effective on the development of strategic thinking in the MAPNA Group Corporation is as follows: organizational structure, organizational creativity and innovation, organizational outlook, reward system, organizational agility and, organizational culture. In addition an incompatibility rate of smaller than 0.1 shows the validity of the judgments. 


\section{DISCUSSION AND CONCLUSION}

Cultural elements that help with the development of strategic thinking include creating culture throughout the entire organizational levels, creation and preservation of a culture that supports effective and moral behaviors, creating a work atmosphere full of positive thoughts, propagation of the culture of innovation and creativity. In fact organizations are suggested to develop their levels of strategic thinking through institutionalization of the effectiveness culture and the spirit of positivism.

Effective elements on the reward system that help with the development of strategic thinking include new methods of rewarding suitable levels of risk taking and establishment of a bond between rewards and extrarole behaviors. In fact organizations can move towards developed strategic thinking through utilization of new methods of rewarding.

Effective elements on systematic view that help with the further development of strategic thinking include organizational values in the minds of employees, understandability of relationships between the major components of the organization, having the strength to systematically understand the organization and institutionalization of concentration on goals in all organizational levels. Organizations are recommended to improve the perceptions of the entire personnel in order to be able to improve strategic thinking.

Effective elements on concentration on goals that result in development of strategic thinking include concentration of organizational resources towards obtaining organizational goals and considering for the most suitable and desirable organizational goals.
It is recommended to work on various organizational resources towards obtaining specifically held goals while developing strategic thinking.

Effective elements on organizational outlook that result in the development of strategic thinking include realization of organizational outlook, proportionality between the outlook, culture and strategies, disregarding short term sources and, application of creativity and innovation while expressing the outlook. Hereby it is recommended to develop strategic thinking through connecting outlook, culture and strategies in order to be able to reinforce strategic thinking.

Effective elements on organizational creativity and innovation that help with the development of strategic thinking include the ability to integrate the existing ideas into new ones and, additional corporate activities for making entry to new and different markets. Hereby it is recommended to pay attention to the ideas, innovations and new thoughts of employees so that strategic thinking is further developed.

Elements effective on organizational agility that help with the development of strategic thinking include: perfect accomplishment of tasks in shortest of times, provision of new and crucial solutions in critical situations, putting various processes in motion through the application of equal facilities and, the ability to detect reactions rapidly. Hereby it is suggested that through the improvement of efficiency and effectiveness, one can help with formation of strategic thinking.

Effective elements on organizational structure that will help with the development of strategic thinking are comprised of versatility of the organizational structure, 
proportionality between the structure and codified strategies and all-aspect communications within the organization. Therefore it is suggested that one can help with the development of strategic thinking through behavioral, skill-related and task-related versatility.

Furthermore, the following are recommended:

- Emphasis on an organizational culture that is in line with creativity and change.

- Spirits of positivism, frankness and honesty.

- Organizational environmental awareness.

- Being able to express disagreements regarding issues.

- Evolution of the urban management plan into corporate management plan.

- Group interactions in organizational thinking.

- Training of thinking.

- Organizational support for thoughts, creative efforts and etc.

- Amendment of structures and processes through increasing strategic discourse.

- Optimization of skills against environmental changes.

- Mitigation of non-necessary actions and planning for elimination of such actions.

- Studying the various existing thinking models in the domains of public services.

- Collaboration and tight emphasis on collaboration.

- Making use of creativity while making decisions, even in tight time lines.

- Making use of scientific methods in making the decisions.

- Making the organization flexible against changes.

- Providing the possibility for creative hypothesis making in the organization.

- Investigation of the effect of environmental changes on the activities of the organization

- Creation of positive attitude towards changes under the title of discovery of new opportunities

- Paying attention to the creation of valuebearing opportunities for the citizens

- The application of ideas of the employees by the managers must be clear and obvious

- Optimization of organizational abilities (technology, human resources, physical resources and etc.)

- Establishment of R\&D units and making use of the results of studies of these units in organizations.

\section{REFERENCES}

BONN, INGRID. Improving Strategic thinking: a multilevel approach. Leadership and Organization Development Journal, Vol 25, 2005.

DAVID, FRED R. Strategic management (12th ed.). New York: Macmillan Publishing Company, 2010.

FARHANGI, ALI AKBAR. DEHGHAN NAYERI, MAHMOUD. Factors Affecting Strategic Thinking. Marketing Management Magazine. Volume 5, No 9, Pp: 20-1, 2010.

GHAFFARIAN. WAFA, KIANI, GHULAM REZA. Strategic Thinking, Tadbir Magazine, Fourth Year. No 137, 2003.

HERACLEOUS, LOIZOS. Strategic Thinking or Strategic Planning?, LongRange Planning, Vol 31, No 3, pp: 481 - 487, 1998. https:// doi.org/10.1016/S0024-6301(98)80015-0 KHORSANDI NOWSHAHRI, HAMED. The role of strategic thinking in changing paradigms 
and taking advantage of opportunities. Master's Thesis. Payame Noor University of Noshahr, 2012.

KIT,PUN FAI. A Conceptual Synergy Model of Strategy Formulation for Manufacturing, International Journal of Operations \& Production Management, Vol 24, No 9, pp: 903-928, 2004. https://doi.org/10.1108/014 43570410552117

LIEDTKA, J.M. Strategic thinking: can it be taught? Long Range Planning, 31, 120-129, 1998. https://doi.org/10.1016/S0024-6301 (97)00098-8

MASHBAKI, ASGHAR, KHAZAEE, ANAHITA. Designing the Model of Strategic Thinking Elements in Iranian Organizations, Journal of Commercial Management, Autumn and Winter, pp: 118-1, 2008.

MINTZBERG, H. Strategy safari. New York: Free Press, 1998.

MINTZBERG, $\mathrm{H}$. The fall and rise of strategic planning, Harvard Business Review, January February, pp: 107-114, 1994.

MINTZBERG, H.AND LAMPEL, J. Reflecting on the strategy process, Sloan Management Review, spring, pp: 2-30, 1999.

MINTZBERG, HENRY. The fall and Rise of strategic planning, Harvard Business Review, Jan-Feb, pp: 107-114, 1994.

MIRAFTABZADEH, SEYYED MEHRDAD, ABBAS MEHRABI AND MARYAM RANJBARAN. Strategic Thinking, Nature, Content and Patterns in Organizations, First Conference on Management and Accounting, Islamic Azad University of Natanz, 2013.

MOUNIRIAN, ABBAS. AGHAZADEH, HASHEM, SHAHAMAT NEZHAD, MINA. Measurement of Strategic Thinking at Tehran Municipality Directors, Business Management, Faculty of Management, University of Tehran, Volume 4. No 12, pp: 129-146, 2012.
NAPIER, NANCY K. \& ALBERT, MARTHA S. East Asian and American perspectives on thinking strategically: The Leopard and His, 1990.

SAIED KALALI, NADER. Key Elements of Thinking Strategically. International Journal of Management, Accounting and Economics, Vol 2, No 8, 2015.

SHAKHSI. R DAVID. Strategic Management, Translator: Dr. Seyed Mohammad Arabi and Dr. Ali Parsaian, Publisher: Office of Cultural Studies, 137, 1999.

YUTARO NEMOTO, KENTARO UEI, TAKASHI FUJIWARA, SATOSHI MIZOGUCHI, YOSHIKI. Shimomura, Strategic Thinking in EDIPS: Edutainment for Designing Integrated Product-service System. Procedia CIRP, Volume 16, pp: 92-97, 2014. https://doi.org/10. 1016/j.procir.2014.01.012 ZAREI, EBRAHIM, GHOLAMI, ALI MOHAMMAD. Strategic Management and Planning, Post Publishing, Tehran, 2010.

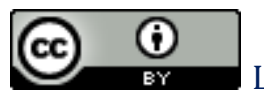
License information: This is an openaccess article distributed under the terms of the Creative Commons Attribution License, which permits unrestricted use, distribution, and reproduction in any medium, provided the original work is properly cited.

Article received on July 22, 2018.

Evaluated August 01, 2018.

Accepted on August 02, 2018.

Published on February 28, 2019.

How cite this article (ABNT):

MONAVARIAN, Abbas; HASHEMI, Mitra. A scientific attempt to Identify and prioritize the elements effective on the development of strategic thinking in the MAPNA Group Corporation. Estação Científica (UNIFAP), Macapá, v. 8, n. 2, p. 35-46, may/apr. 2018. 